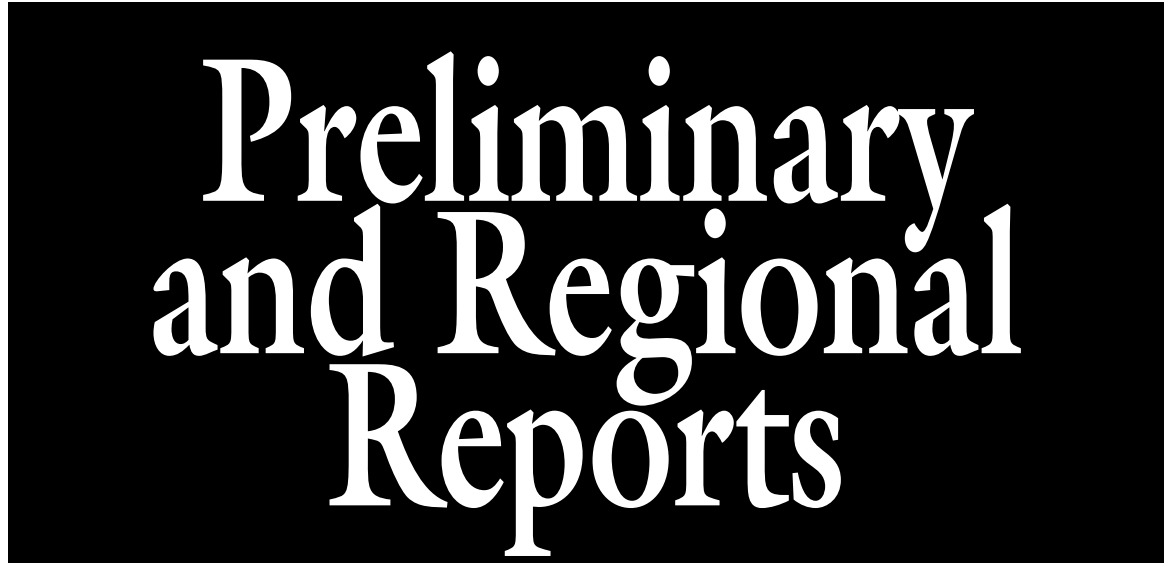

\title{
Determining Optimal Production Temperature, Transplant Stage, and Postharvest Protocols for Cut 'Esprit' Penstemon
}

\author{
Alicain S. Carlson ${ }^{1}$ and John M. Dole
}

\begin{abstract}
AdDitional Index words. beardtongue, cold storage, ethylene, Penstemon grandiflorus, preservative
\end{abstract}

Summary. The effects of production temperature and transplant stage on stem length and caliper of cut stems and postharvest treatments on vase life of 'Esprit' penstemon (Penstemon grandiflorus) were examined. Plugs transplanted with eight to nine sets of true leaves had a longer stem length $(64.3 \mathrm{~cm})$ at harvest than those transplanted with two to three sets $(57.7 \mathrm{~cm})$ or five to six sets $(60.8 \mathrm{~cm})$. Time to flowering from transplant shortened as production temperature increased and when transplants had a greater number of true leaves. The addition of $2 \%$ or $4 \%$ sucrose with $7 \mathrm{ppm}$ isothiazolinone as a vase solution resulted in the longest vase life (9.4 days) of all treatments compared with the control (4.5 days). A holding solution increased vase life to 7.0 days for Floralife holding solution and $\mathbf{5 . 9}$ days for Chrysal holding solution from the 4.3 days control, although hydrating solutions and preservative brand had no effect. The use of floral foam or antiethylene agents, ethylene exposure, or sucrose pulses also had no effect on vase life. Extended cold storage lengths either wet or dry for 2 or 3 weeks caused vase life to decrease to 2.0 days when compared with 5.6 days for the unstored control and 7.6 days for 1 week storage. 'Esprit' penstemon may be suitable for greenhouse production and has acceptable potential as a locally grown specialty cut flower.

$\mathrm{N}$ ew cut flower introductions are a necessity to maintain and increase consumer interest. Expanding the availability and knowledge of new cut flowers allows growers to pick species ideally suited for their climate and consumer base. Many garden ornamental species are

Department of Horticultural Science, North Carolina State University, Campus Box 7609, Raleigh, NC 27695

We gratefully acknowledge funding from the Hill Foundation, the Association of Specialty Cut Flower Growers Association Research Foundation, and the American Floral Endowment and support from the floriculture research technicians Ingram McCall and Diane Mays as well as former graduate students Emma Locke and Erin Clark.

${ }^{1}$ Corresponding author. E-mail: ascarlso@ncsu.edu. underused by the floral industry, such as beardtongues (Penstemon sp.). Largeflowered beardtongue ( $P$.grandiflorus) has the largest flowers and the greatest color range (31 different distinct color shades) of all beardtongue species (Way and James, 1998). Current cultivars being produced as cut flowers have much smaller flowers that are muted pink, purple, or white in coloration. 'Esprit' penstemon (Fig. 1) would offer growers a showy, vibrant colored flower mix. New cultivars and species may appear to have potential, but growers are hesitant to produce new cut flower crops without information on production and postharvest techniques.

Determining the age at which a young plant can be transplanted successfully is essential to obtain quality plants and reduce production costs (Cavins and Dole, 2001; van Iersel, 1997). Although it may be more economical to leave plants in plug trays for as long as possible before transplanting to the final production area to allow a greater number of crops to be harvested in a season, prolonged duration in the plug flats can stunt growth and cause plants to have fewer, shorter, or thinner stems that do not produce quality flowers due to excessive root restriction (Donnell, 2006; van Iersel, 1997). It is also important for growers to know optimal production temperatures before growing a new crop. Each plant species has a range of temperatures that are tolerable and allow plant growth, but extreme temperatures within that range can stress plants resulting in pest/disease problems, unacceptably long production times, or reduced inflorescence quality (Dole and Wilkins, 2005).

A number of factors influence vase life after harvest, including ethylene, storage temperatures, sucrose pulses, and commercial preservatives.

\begin{tabular}{llll}
\hline $\begin{array}{l}\text { Units } \\
\text { To convert U.S. to SI, } \\
\text { multiply by }\end{array}$ & U.S. unit & SI unit & $\begin{array}{l}\text { To convert SI to U.S., } \\
\text { multiply by }\end{array}$ \\
\hline 10 & $\%$ & $\mathrm{~mL} \cdot \mathrm{L}^{-1}$ & 0.1 \\
29.5735 & $\mathrm{fl} \mathrm{oz}$ & $\mathrm{mL}$ & 0.0338 \\
3.7854 & gal & $\mathrm{L}$ & 0.2642 \\
2.54 & inch $(\mathrm{es})$ & $\mathrm{cm}$ & 0.3937 \\
25.4 & inch $(\mathrm{es})$ & $\mathrm{mm}$ & 0.0394 \\
1 & $\mathrm{mmho} / \mathrm{cm}$ & $\mathrm{dS} \cdot \mathrm{m}^{-1}$ & 1 \\
28,350 & $\mathrm{oz}$ & $\mathrm{mg}$ & $3.5274 \times 10^{-5}$ \\
1 & $\mathrm{ppb}$ & $\mathrm{nL} \cdot \mathrm{L}^{-1}$ & 1 \\
1 & $\mathrm{ppm}$ & $\mathrm{mg} \cdot \mathrm{L}^{-1}$ & 1 \\
0.001 & $\mathrm{ppm}$ & $\mathrm{mL} \cdot \mathrm{L}^{-1}$ & 1000 \\
1 & $\mathrm{ppm}$ & $\mu \mathrm{L} \cdot \mathrm{L}^{-1}$ & 1 \\
$\left({ }^{\circ} \mathrm{F}-32\right) \div 1.8$ & ${ }^{\circ} \mathrm{F}$ & ${ }^{\circ} \mathrm{C}$ & $\left({ }^{\circ} \mathrm{C} \times 1.8\right)+32$
\end{tabular}




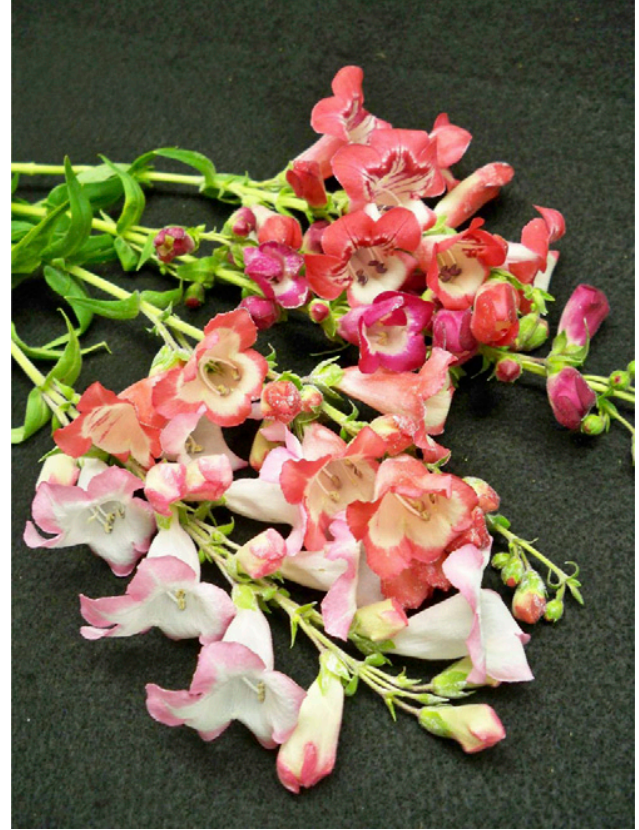

Fig. 1. Cut stems of 'Esprit' penstemon.

Ethylene exposure can have deleterious effects on cut flowers. Selected species of beardtongue are sensitive to ethylene, including foxglove beardtongue ( $P$. digitalis), which results in flower abscission and reduced vase life (Redman et al., 2002). Treating cut stems with 1-methylcyclopropene (1-MCP) or silver thiosulfate (STS) has been shown to reduce the negative effects of ethylene exposure on some cut flower species (Dole and Wilkins, 2005).

Cooling retards the utilization of carbohydrates during respiration, which extends postharvest life and delays development in most species (Sacalis, 1993). A desirable quality of a cut flower is the ability to be shipped long distances out of water (dry) without an adverse effect on vase life. Despite the benefits of cold and dry storage, some flower species do not respond well.

Pretreatments are used to extend vase life and are applied before holding in floral preservatives (Hunter, 2000). Sucrose pulses are a pretreatment used to increase vase life by loading stems with sugar to facilitate the storage of carbohydrates before they are dry packed and shipped long distances or held in storage for long periods of time (Hunter, 2000; Nowak and Rudnicki, 1990). Effective concentrations depend on the species and can have variable effects (Mohan Ram and Ramanuja Rao, 1977), but generally range anywhere from $1 \%$ to 20\% (Dole and Wilkins, 2005).

Commercial preservatives extend the vase life of many species, but may have no effect on others (Sacalis, 1993). Typically, floral preservatives can be categorized as hydrating, holding, or vase solutions. Holding solutions contain a carbohydrate source to encourage bud opening and/or flower longevity and are applied for $\approx 1-2 \mathrm{~d}$. Hydrating solutions are meant to be applied before a holding solution right after harvest for $\approx 4$ h to facilitate water uptake and do not contain a carbohydrate source (Dole and Wilkins, 2005). Vase solutions are generally applied by the consumer and contain a lower concentration of carbohydrates than a holding solution. The ability for new cut flowers to perform well in floral foam is also important, especially to floral designers.

The objectives of this study were to determine optimal production temperature, transplant stage, and postharvest procedures, including commercial preservatives, ethylene sensitivity, sucrose pulses, and cold storage for 'Esprit' penstemon to be considered for use as a new cut flower introduction.

\section{Materials and methods}

Production-year 1. 'Esprit' penstemon seeds (Park Seed Co., Greenwood, SC) were sown on 3 Feb. 2009 into 105-cell plug trays using a commercial peat-based root substrate (Fafard 4P Mix; Conrad Fafard, Agawam, MA) and germinated at $21^{\circ} \mathrm{C}$. Plants were fertigated with $250 \mathrm{ppm}$ nitrogen (N) from a premixed commercial $20 \mathrm{~N}-4.4 \mathrm{P}-$ $16.6 \mathrm{~K}$ fertilizer (Peter's, Allentown, PA) during the week and irrigated with clear water on the weekends. Seedlings were transplanted into plastic lily crates $(22 \times 14.5 \times 9$ inches $)$ using the same substrate as above at the appearance of two to three, five to six, or eight to nine sets of true leaves, which were 59, 81, and $106 \mathrm{~d}$ after sowing, respectively. Fifteen plugs were transplanted in each crate at $4 \times 4-\mathrm{cm}$ spacing and placed at $19 \pm 3 / 23 \pm 3$ or $22 \pm 1 / 25 \pm 1{ }^{\circ} \mathrm{C}$ (night/day) air temperatures in glass-covered greenhouses. There were 10 crates per transplant stage, randomized within each temperature treatment. Temperature was recorded hourly for the duration of the experiment. Stem length, caliper (measured $\approx 5 \mathrm{~cm}$ below the bottom floret), and anthesis date were recorded. Only marketable stems were harvested. A stem was considered marketable when the length was greater than $30 \mathrm{~cm}$ and florets were unblemished.

Production-year 2. A second year of production was used to test alternative production temperatures from year 1 . Seeds were sown on 11 Nov. 2010 in the same manner as above and transplanted on 17 Feb. 2011 into plastic lily crates at the appearance of eight to nine sets of true leaves. Fifteen plugs were transplanted in each crate at $4 \times 4-\mathrm{cm}$ spacing and placed at $18 \pm 5 / 24 \pm 5,20 \pm 2 / 25 \pm$ 2 , or $21 \pm 2 / 26 \pm 2{ }^{\circ} \mathrm{C}$ (night/day) air temperatures in double-layered polyethylene plastic-covered greenhouses. There were seven crates per treatment. Stem length, caliper, anthesis date, and number of marketable and unmarketable stems per crate were recorded.

Postharvest handling. Inflorescences from year 1 of production were harvested when at least a quarter of the florets were open on each inflorescence, placed in tap water $[0.21$ $\mathrm{dS} \cdot \mathrm{m}^{-1}$ electrical conductivity (EC), 6.1 $\mathrm{pH}]$, recut after hydrating for $\approx \mathrm{l} h$, and placed in the treatments outlined below. Stems from the two different production temperatures were sorted into treatments evenly when necessary. After treatment all stems were recut if 
needed and placed into vases of deionized (DI) water $\left(0.00 \mathrm{dS} \cdot \mathrm{m}^{-1} \mathrm{EC}, 4.4\right.$ $\mathrm{pH}$ ) with one stem per vase until termination unless otherwise noted. Stems were held in a postharvest environment at $21 \pm 2{ }^{\circ} \mathrm{C}$ air temperature under $20 \mu \mathrm{mol} \cdot \mathrm{m}^{-2} \cdot \mathrm{s}^{-1}$ light for 12 $\mathrm{h} \cdot \mathrm{d}^{-1}$ at $40 \%-60 \%$ relative humidity until termination. A stem was considered ready to end when $50 \%$ of the florets had either wilted or abscised or the stem bent past a $90^{\circ}$ angle. A completely randomized design was used with five to ten stems per treatment; treatments were arranged in a factorial where appropriate. Each set of treatments included a DI water control.

Ethylene sensitivity. Cut stems were placed into 55 -gal sealed steel drums and pretreated for $4 \mathrm{~h}$ with STS $11 \mathrm{~mL}$ AVB (Pokon \& Chrysal, Miami, FL) per liter DI water] or 1-MCP [400 mg Ethylbloc (Floralife, Walterboro, SC) dissolved in $50 \mathrm{~mL}$ DI water at $30{ }^{\circ} \mathrm{C}$ for a final concentration of $700 \mathrm{ppb}$ 1-MCP gas in the drum], then placed in DI water and subjected to $0,0.1$, or $1.0 \mathrm{ppm}$ ethylene for $16 \mathrm{~h}$ in the same sealed drums.

Cold storage duration. Cut stems were held for 1,2 , or 3 weeks at $2 \pm 2{ }^{\circ} \mathrm{C}$ and $65 \%-75 \%$ relative humidity either dry packed in floral boxes lined with newspaper or wet in buckets of DI water.

Sucrose Pulses. Stems received a 24-h pulse of $7 \mathrm{ppm}$ isothiazolinone (Kathon CG; Rohm \& Haas, Philadelphia, PA) and either $0 \%, 10 \%$, or $20 \%$ sucrose in DI water.

VASE SOLUTIONS AND SUBSTRATES. Cut stems were placed in vases with $7 \mathrm{ppm}$ isothiazolinone, with or without floral foam (Instant Deluxe floral foam; Smithers-Oasis Co., Cuyahoga Falls, $\mathrm{OH}$ ) and either $0 \%, 2 \%$, or $4 \%$ sucrose in floral solution until termination.

Commercial preservatives. Cut stems were pretreated for $4 \mathrm{~h}$ with one of three solutions: two commercial hydrating solutions [Chrysal Professional 1 (Pokon \& Chrysal) at $8 \mathrm{~mL} \cdot \mathrm{L}^{-1}$ or Hydraflor 100 (Floralife) at $2 \mathrm{~mL} \cdot \mathrm{L}^{-1}$ ] or DI water and placed for $2 \mathrm{~d}$ in one of three holding solutions: two commercial holding solutions (Chrysal Professional 2 at $10 \mathrm{~mL} \cdot \mathrm{L}^{-1}$ or Floralife Professional at $\left.10 \mathrm{~mL} \cdot \mathrm{L}^{-1}\right)$ or DI water.

Statistical analysis. All production and postharvest data were analyzed using analysis of variance procedures using the general linear models procedure and means were separated using Tukey's multiple comparison procedure at $P \leq 0.05$ using SAS (version 9.3; SAS Institute, Cary, NC).

\section{Results}

\section{Production-year 1}

As the production temperature increased from 19 to $22{ }^{\circ} \mathrm{C}$, stem caliper decreased from 3.6 to $3.3 \mathrm{~mm}$ (Table 1). Production temperature had no significant effect on stem length or days to flower from transplanting. Plants grown at $19{ }^{\circ} \mathrm{C}$ produced 8.2 marketable stems per crate compared with 1.0 stem per crate in the $22{ }^{\circ} \mathrm{C}$ treatment. Plugs transplanted with eight to nine sets of true leaves had the longest stem length, thinnest caliper, and shortest time to flower compared with the other two transplant stages (Table 1). There were no significant interactions between production temperature and transplant stage.

Table 1. Effects of production night air temperature and pairs of true leaves at transplant stage for year 1 on stem length, caliper, and time to anthesis from transplanting for 'Esprit' penstemon. Production temperature regimes were: $19 \pm 3 / 23 \pm 3$ and $22 \pm 1 / 25 \pm 1{ }^{\circ} \mathrm{C}$ (night/day) air temperatures.

\begin{tabular}{|c|c|c|c|}
\hline Treatments & Length $(\mathrm{cm})^{\mathrm{z}}$ & Caliper $(\mathrm{mm})^{\mathrm{z}}$ & Time to anthesis $(\mathrm{d})$ \\
\hline \multicolumn{4}{|c|}{ Night air temp $\left({ }^{\circ} \mathrm{C}\right)^{\mathrm{z}}$} \\
\hline 19 & 60.5 & $3.6 b^{y}$ & 93 \\
\hline 22 & 57.5 & $3.3 \mathrm{a}$ & 86 \\
\hline Significance $^{\mathrm{x}}$ & NS & 0.04 & NS \\
\hline \multicolumn{4}{|c|}{ Pairs of true leaves at transplant stage (no.) } \\
\hline $2-3$ & $57.7 \mathrm{a}$ & $3.6 \mathrm{~b}$ & $113 \mathrm{c}$ \\
\hline $5-6$ & $60.8 \mathrm{~b}$ & $3.5 \mathrm{~b}$ & $81 \mathrm{~b}$ \\
\hline $8-9$ & $64.3 \mathrm{c}$ & $3.3 \mathrm{a}$ & $69 \mathrm{a}$ \\
\hline Significance & $<0.01$ & $<0.01$ & $<0.01$ \\
\hline
\end{tabular}

${ }^{\mathrm{z}}\left(1.8 \times{ }^{\circ} \mathrm{C}\right)+32={ }^{\circ} \mathrm{F}, \mathrm{l} \mathrm{cm}=0.3937$ inch, $1 \mathrm{~mm}=0.0394$ inch.

${ }^{y}$ Means followed by the same letter are not significantly different according to Tukey's multiple comparison at $\alpha=0.05$.

${ }^{x} P$ values were obtained using General Linear Models (GLM) procedures of SAS.

Table 2. Effects of production night air temperature for year 2 on stem length, time to anthesis from transplanting, and percentage of marketable stems for 'Esprit' penstemon. Production temperature regimes were: $18 \pm 5 / 24 \pm 5,20 \pm$ $2 / 25 \pm 2$, and $21 \pm 2 / 26 \pm 2{ }^{\circ} \mathrm{C}$ (night/day) air temperatures. $\begin{array}{llll}\text { Night air temp }\left({ }^{\circ} \mathrm{C}\right)^{\mathrm{z}} & \text { Length }(\mathrm{cm})^{\mathrm{z}} & \text { Time to anthesis (d) } & \text { Marketable stems (\%) }\end{array}$

\begin{tabular}{llcc}
\hline 18 & $45.9 \mathrm{a}^{\mathrm{y}}$ & $107 \mathrm{~b}$ & $87 \mathrm{a}$ \\
20 & $62.9 \mathrm{c}$ & $97 \mathrm{a}$ & $99 \mathrm{~b}$ \\
21 & $56.8 \mathrm{~b}$ & $94 \mathrm{a}$ & $100 \mathrm{~b}$ \\
Significance $^{\mathrm{x}}$ & $<0.01$ & $<0.01$ & $<0.01$ \\
\hline
\end{tabular}

${ }^{\mathrm{z}}\left(1.8 \times{ }^{\circ} \mathrm{C}\right)+32={ }^{\circ} \mathrm{F}, 1 \mathrm{~cm}=0.3937$ inch.

${ }^{y}$ Means followed by the same letter are not significantly different according to Tukey's multiple comparison at $\alpha=0.05$.

${ }^{\times} P$ values were obtained using General Linear Models (GLM) procedures of SAS. 
vase life to decrease to $2.0 \mathrm{~d}$ when compared with $5.6 \mathrm{~d}$ for the unstored control and $7.6 \mathrm{~d}$ for 1 week storage $(P<0.01)$. There was no significant difference between stems stored wet or dry $(P=0.4 \mathrm{l})$ and no significant interactions (data not presented).

Sucrose pulses $(N=7)$. The use of a $10 \%$ or $20 \%$ sucrose pulse did not have a significant effect on vase life $(P=0.78)$. The addition of $7 \mathrm{ppm}$ isothiazolinone increased vase life to $7.7 \mathrm{~d}$ from $4.7 \mathrm{~d}$ for the control $(P=$ 0.05 ) (data not presented). There were no significant interactions.

VASE SOLUTIONS AND SUBSTRATES $(N=10)$. The addition of either $2 \%$ or $4 \%$ sucrose increased vase life to $8.9 \mathrm{~d}$ from the control of $5.3 \mathrm{~d}(P<0.01)$, but there was no significant difference between $2 \%$ or $4 \%$ sucrose (data not presented). The addition of isothiazolinone also increased vase life from 4.5 to $6.0 \mathrm{~d}(P=0.04)$. The longest vase life of $9.4 \mathrm{~d}$ resulted from stems held in a solution of $4 \%$ sucrose along with $7 \mathrm{ppm}$ isothiazolinone, but this was not statistically different from $2 \%$ sucrose along with isothiazolinone $(8.5 \mathrm{~d})$ (data not presented). The use of floral foam did not affect vase life. There were no significant interactions.

Commercial preservatives $(N=7)$. A holding solution increased vase life to $7.0 \mathrm{~d}$ for Floralife holding solution and $5.9 \mathrm{~d}$ for Chrysal holding solution from $4.3 \mathrm{~d}$ for the DI water control $(P=0.01)$. The use of a hydrating solution, with or without the subsequent use of a holding solution, had no effect on vase life. There was no difference between brand (Floralife or Chrysal) used in all treatments (data not presented). No significant interactions occurred.

\section{Results and discussion}

Holding plugs in trays until eight to nine sets of true leaves form appears to have no commercially significant negative effects on stem length and caliper and plants flowered more quickly. Plugs transplanted with eight to nine sets of true leaves resulted in longer stem lengths, which is important for cut flower production. Longer stem lengths may be due to competition for light while in the plug trays. Stem caliper was not decreased enough to be commercially significant. Plants can be left in the plug trays $\approx 47 \mathrm{~d}$ longer than those transplanted at two to three sets, which will allow more crops to be grown in the finishing area each year. Holding plugs until eight to nine sets of true leaves did not appear to cause root restriction significant enough to affect cut stem quality. 'Esprit' penstemon was treated as an annual crop so long-term effects were not examined.

In the two production temperatures tested in year $1\left(19\right.$ and $\left.22^{\circ} \mathrm{C}\right)$, the $22^{\circ} \mathrm{C}$ temperature decreased time to flower, but stems were thinner compared with stems from the $19^{\circ} \mathrm{C}$ treatment. The decrease in stem caliper was statistically significant, but the $0.3 \mathrm{~mm}$ difference was not commercially significant enough to make the stems unusable. In addition, in the $22{ }^{\circ} \mathrm{C}$ treatment there was high plant mortality due to damage from western flower thrips (Frankliniella occidentalis) and two-spotted spider mites (Tetranychus urticae) (personal observation). Despite appropriate measures to control pests, by 18 June 2009 , $28 \%$ of the crates were culled due to insects and disease in the $22{ }^{\circ} \mathrm{C}$ treatment, whereas no crates were culled from the $19{ }^{\circ} \mathrm{C}$ treatment (personal observation).

Additional production temperatures were tested in year 2 to determine if a temperature between 19 and $22{ }^{\circ} \mathrm{C}$ would allow a shorter production time and healthier plants without affecting stem quality (length and caliper). There was little difference between production temperatures of 20 and $21{ }^{\circ} \mathrm{C}$, except for a $6.1 \mathrm{~cm}$ difference in stem length, which was statistically significant, but did not affect the number of marketable stems. Production time was not shortened in any of the temperatures tested the second year and was longest for the $18{ }^{\circ} \mathrm{C}$ temperature of $107 \mathrm{~d}$. A similar pest problem as in the first year occurred again in the $18{ }^{\circ} \mathrm{C}$ house as compared with the $22{ }^{\circ} \mathrm{C}$ house the previous year that caused stunted growth and reduced stem quality, which reflected in the reduced number of marketable stems. Western flower thrips and two-spotted spider mites are common greenhouse pests that are hard to control and appropriate actions were taken to manage them. A direct relation to the differences in the number of marketable stems or stem quality to production temperature cannot be accurately made because insect pressure can also play a role in plant quality; however, production temperatures can have an effect on pest populations. Each plant species has a range of temperatures that are tolerable and allow plant growth, but extreme temperatures within that range can stress plants resulting in pest/disease problems, unacceptably long production times, or reduced inflorescence quality (Dole and Wilkins, 2005). It is possible that the 22 and $18{ }^{\circ} \mathrm{C}$ production temperatures were not optimal for 'Esprit' penstemon and thus made them more susceptible to insect pests; however, there may have been some confounding variables that attributed to the pest problems.

The use of a commercial holding solution increased vase life making our results consistent with other beardtongue species. Ten species of beardtongue including foxglove beardtongue, large-flowered beardtongue, and buckley beardtongue (P. buckleyi), responded positively to the addition of Floralife (specific product unspecified) to the vase water, sometimes even doubling vase life (Lindgren, 1986). The addition of $7 \mathrm{ppm}$ of the biocide isothiazolinone had a positive effect on vase life most likely by keeping stem vasculature free from bacteria, yeast, and fungi that can limit water uptake. Sucrose pulses had no significant effect on vase life of 'Esprit' penstemon. Redman et al. (2002) found that pretreating foxglove beardtongue for 24 -h with an $8 \%$ sucrose solution reduced vase life; however, we found a $2 \%$ or $4 \%$ sucrose vase solution to increase vase life. These studies suggest that 'Esprit' penstemon would benefit from a long-term holding solution with a low concentration of sucrose rather than a highconcentration, short-term pulse. In addition, production temperatures from year one did not have a significant effect on vase life.

'Esprit' penstemon differs from other beardtongue species in its cold storage capability. Cut stems appear to tolerate wet or dry storage at $2{ }^{\circ} \mathrm{C}$ for no more than 1 week, which is acceptable for shipping or storing surplus. Studies done with foxglove beardtongue have shown that it can tolerate 2 weeks of storage at $2{ }^{\circ} \mathrm{C}$ without a significant effect on vase life (Lindgren et al., 1988; Redman et al., 2002). 
'Esprit' penstemon would be suited for florists and design uses because floral foam did not have a significant negative effect on vase life. The application of exogenous ethylene along with pretreatment with antiethylene agents had no effect on vase life and closed buds continued to open, which is contrary to other studies that used different species of beardtongue. The application of exogenous ethylene $(0.2$ or $1 \mathrm{ppm})$ to foxglove beardtongue decreased its vase life, but treatment with STS had no effect (Redman et al., 2002). Serek et al. (1995) found that the longevity of 'Firebird' penstemon (P. hartwegii $\times$ $P$. cobaea 'Firebird') increased by $\approx 3 \mathrm{~d}$ when pretreated with 1-MCP. Staby et al. (1993) also used 'Firebird' penstemon and found that STS greatly reduced or completely inhibited flower abscission.

\section{Conclusion}

An exact temperature recommendation is not clear for 'Esprit' penstemon, but these results may suggest that it be grown around a 20 to $21^{\circ} \mathrm{C}$ mean night temperature. More work still needs to be done to solidify this recommendation. Plants should be monitored carefully for signs of stress and insect pests and managed as needed. Transplanting plugs when they have eight to nine sets of true leaves is economical without compromising quality. It may be possible to hold the plugs in the trays for a longer duration than tested to further reduce costs and space requirements. This species may also be suited for field or high tunnel production, but needs to be evaluated.
'Esprit' penstemon would be acceptable for specialty cut flower growers who sell their product locally where product is often cut the day of or the day before it is sold. The stems need to be held in a commercial holding solution or a $2 \%$ sucrose vase solution with a biocide to provide a vase life of at least $7 \mathrm{~d}$. Commercial holding and vase solutions contain a biocide and would be the easiest option for growers and consumers. If the flowers are held by the retailer or grower for at least $2 \mathrm{~d}$ in a holding solution, vase life should be acceptable for the consumer. Consumers usually place their flowers in plain tap water rather than in preservative solutions, but increasingly growers and retailers are providing their customers with preservative sachets. 'Esprit' penstemon has desirable postharvest characteristics, like tolerance to dry shipping and floral foam, but its commercial potential may be restricted because preservatives or antimicrobial compounds are required for an acceptable vase life.

\section{Literature cited}

Cavins, T.J. and J.M. Dole. 2001. Photoperiod, juvenility, and high intensity lighting affect flowering and cut stem qualities of Campanula and Lupinus. HortScience 36:1192-1196.

Dole, J.M. and H.F. Wilkins. 2005. Floriculture: Principles and species. 2nd ed. Prentice Hall, Upper Saddle River, NJ.

Donnell, A.A. 2006. Effect of plug flat on plant growth and prevention of posttransplant stunting. MS Thesis, North Carolina State Univ., Raleigh.
Hunter, N.T. 2000. The art of floral design. Thomson Delmar Learning, Clifton Park, NY.

Lindgren, D.T. 1986. Penstemon as cut flowers. Bul. Amer. Penstemon Soc. 45:19-21.

Lindgren, D.T., D. Whitney, and J. Fitzgerald. 1988. Response of cut flower spikes of Penstemon digitalis 'Husker Red' to floral preservatives and chilling periods. Bul. Amer. Penstemon Soc. 47:7-8.

Mohan Ram, H.Y. and I.V. Ramanuja Rao. 1977. Prolongation of vase-life of Lupinus hartwegii Lindl. by chemical treatments. Sci. Hort. 7:377-382.

Nowak, J. and R.M. Rudnicki. 1990. Postharvest handling and storage of cut flowers, florist greens, and potted plants. Timber Press, Portland, OR.

Redman, P.B., J.M. Dole, N.O. Maness, and J.A. Anderson. 2002. Postharvest handling of nine specialty cut flower species. Sci. Hort. 92:293-303.

Sacalis, J.N. 1993. Cut flowers: Prolonging freshness. 2nd ed. Ball Publ., Batavia, IL.

Serek, M., E.C. Sisler, and M.S. Reid. 1995. Effects of 1-MCP on the vase life and ethylene response of cut flowers. Plant Growth Regulat. 16:93-97.

Staby, G.L., R.M. Basel, M.S. Reid, and L.L. Dodge. 1993. Efficacies of commercial anti-ethylene products for fresh cut flowers. HortTechnology 3:199-202.

van Iersel, M. 1997. Root restriction effects on growth and development of salvia (Salvia splendens). HortScience 32:1186-1190.

Way, D. and P. James. 1998. The gardeners guide to growing penstemons. Timber Press, Portland, OR. 